\title{
国立高専における原子力人材育成について
}

国立高等専門学校機構 紀 聖治

原子力発電所で即戦力となる技術者育成について，地元の高等専門学校(高専)の果たす役割は大き く, 近年では, 就職希望者の約 1 割が原子力関係に就職している。高専では正式カリキュラムとして原 子力関係講座を持たないが, 卒業生の地元関連企業採用ニーズに対応し, 原子力人材育成ネットワーク を通じた原子力系大学，産業界等との連携により，原子力教育を実施している。

高専独自に教育カリキュラムを開発し, 講義, 実験, 施設見学等を授業に組み込んで実施しているほ か, 高専の全国ネットワークを活用して，共通テキストの作成・利用，学内放射線量測定結果の持ち寄 り等により, 教育効果の向上を図っている。平成 22 年度からは文部科学省国際原子力人材育成イニシ アティブ事業に取り組んでおり, その内容について報告する。また連携先である長岡技術科学大学にお ける取組も紹介する。

KEYWORDS: National Institute of Technology, Nagaoka University of Technology, education in nuclear technology, remote education

\section{I．（独）国立高等専門学校機構(国立高専機 構)における原子力教育}

国立高専では，高専制度設置時より，実験実習を重視 したものづくり教育によって, 広い工学分野での開発型 の実践的技術者育成を行ってきた。近年では, 就職希望 者の約 1 割が卒業後に原子力関係事業所に就職して, 原 子力産業界に必要な実践的で開発能力を持った専門技術 者として活躍している。

一方で, 国立高専には原子力関係の学科や専攻は設置 されていないため, 原子力関係・放射線関係の教育は主 に, 物理, 工学基礎物理などの科目や電気・電子あるい は物質工学の専門工学で実施している。これを補うため 平成 22 年度に文部科学省 機関横断的な人材育成事業に よりフィージビリティスタディを 23 の国立高専が参加 して実施し, さらに, 平成 23 年度から平成 25 年度まで は「機関連携による防災・安全教育を重視した実践的原 子力基礎技術者育成の実施」の題名で文部科学省, 機関 横断的な国際原子力人材育成イニシアティブ事業を 33 の国立高専で実施した。さらに，平成 26 年度からは全 国の全ての高専 51 校が参加して，平成 28 年度までの同 事業を実施中である。これらの取り組みなどについて報 告する。

Education for human resource development in the nuclear field in National Institute of Technology: Seiji Kino, Eiji Takada, Shigekazu Suzuki, Yasuo Ohta, Tatsuya Suzuki.

(2015 年 5 月 18 日 受理)

\section{1. 高専制度と原子力教育}

(1) 国立高専とその教育について

国立高専は，我が国経済の高度成長を背景に，産業界 からの強い要望に応えるため昭和 36 年に設立された。 実践的技術者の養成を目指し，中学校卒業者を入学資格 とする 5 年制の高等教育機関として学校教育法の改正に より，工業に関する高等専門学校を制度化して発足し た。さらに, 昭和 42 年からは, 商船に関する学科の設置 を制度化し，国立商船高等専門学校 5 校が発足した。平 成 3 年には, 5 カ年の本科課程の延長として, 大学 3,4 年課程に相当する専攻科課程が発足した。さらに，平成 16 年には全国の国立高専がひとつとなる独立行政法人 体制に移行した。現在では，国立高専機構の下に51の 高専が全国に設置されている。高専教育の特徵は高校・ 大学と同等な内容の教育を本科 5 力年で行うことにあ り, 独特のカリキュラムのもとに高い密度の教育を行っ ている。

国立高専機構では，就学者に対する教育の質の保証 と, さらに各高専の特色ある教育を行うため, 平成 24 年 より「モデルコアカリキュラム (試案)」を全国の高専で試 行している。モデルコアカリキュラムの枠組みにおける 「コア」部分は共通して扱うべき項目で構成され，「モデ ル」部分は, 先導的な取組事例を全高専が共有し, 各高専 の実情に応じて導入・普及を図るものとなっている。

一方, 国のエネルギー基本計画においては原子力発電 が「重要なベースロード電源」と位置付けられ，今後重要 性を増すバックエンド技術等に関連する問題に対応する ため，高専においても当該分野の実践的技術者の育成を 
行う教育体制を構築する必要があると考えられる。特 に，(1)幅広い工学的基盤をもつ国際性の高い技術者，(2) 原子力工学・放射線工学知識を持った技術者の育成が必 要と考えている。高専によっては，モデルコアカリキュ ラムの「モデル」部分に原子力に関する教育を導入してい る場合もある。しかし，第 1 図に示すように多数の学生 が原子力企業・関連企業等へ就職しているにもかかわら ず，基本的には高専教育の中で原子力・放射線に関する 体系だったカリキュラムは未整備であり，それを補う取 り組みが必要となっている。

\section{2. 文科省予算による原子力人材育成事業}

高専には原子力・放射線を主に扱う学科・専攻は現在 のところ設置されていない。それを補うため，長岡技術 科学大学(長岡技科大) と連携して, 日本原子力研究開発 機構 (原子力機構)の協力により, 平成 26 年度からは全 国の 51 高専 55 キャンパスが参加する形で，機関横断的 な原子力人材育成事業「国立高専における原子力基礎工 学分野での教育システムの確立」と題した事業を実施し ている。以下，その内容を紹介する。

（1）実習・インターンシップ

原子力機構，長岡技科大における原子力関連実習を実 施している。実習期間は 1 週間とし，国立高専における インターンシップ単位として認定可能としている。原子 力機構における実習は大洗の放射線取扱施設で行われ, 原子力の基礎，原子炬の安全性等の講義に加え，材料試 験炉 (JMTR)等の見学を実施した。また，JMTRにおけ る動特性実習,「常陽」の運転訓練シミュレー夕実習, 高 温工学試験炉 (HTTR)の安全性に関する実習も実施し た。一方, 国立高専機構内部の実習として, 富山高専, 松江高専，福島高専でも実習を行った。各高専で実習を 行うことで, 高専全体の原子力人材育成のレベルを向 上・維持することも目指している。平成 26 年度の実習 参加者は, 合計 62 名であった。(第 2 図)

\section{（2）遠隔 TV 講義および実習}

平成 26 年度からの事業では, 高専における原子力・放

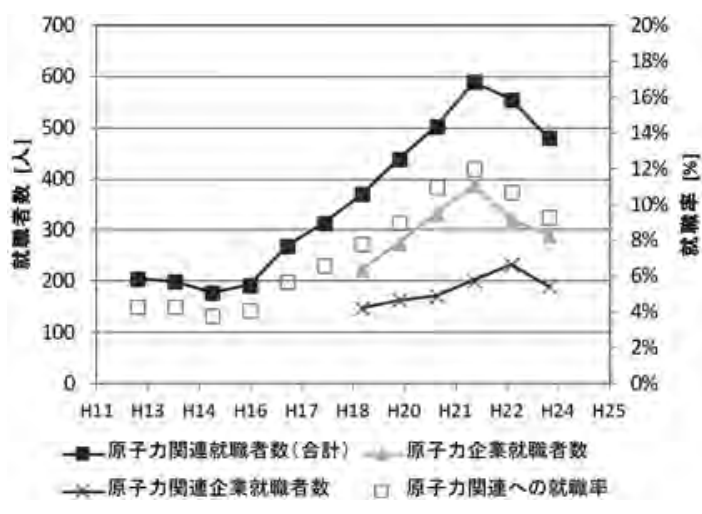

第 1 図 国立高専から原子力関係への就職状況 (「原子力企業」は電力会社および業務が原子力関係中 心である研究所・企業を指し，「原子力関連企業」は原 子力関係の業務も行うメーカー等企業を意味する。）
射線関連教育の体系化を目指し，高専一長岡技科大，豊 橋技科大の間で整備されている $\mathrm{TV}$ 会議システム (GI-net)を活用したTV 講義を開講し, 平成 26 年度に は 9 回の講義を実施した。内容は, (1)概論(わが国のエ ネルギー需給等), (2)放射線基礎, (3)放射線計測, (4)原子 炉の構成と物理，(5)核燃料サイクル，(6)原子炉材料，(7) 放射線防護，8原子力とシステム安全，9核融合からな り, 原子力関係の大学教員および研究所の研究者による それぞれの専門分野の講義を実施した。全高専を対象と する TV 講義は原子力以外の分野を含めても初めての 試みであり，聴講した学生にも貴重な機会であるととら えられた。平成 27 年度以降はリアルタイムアンケート システムを活用するなどして，学生の集中力を保つよう 工夫していく予定である。平成 26 年度には, 9 回の延べ 人数で 957 名の学生が講義を聴講した。平成 26 年度の 講義は外部専門家に全て依頼したが，高専における原子 力・放射線関係の教育技術の向上を目指し，平成 27 年度 には原子力および核融合関連の大学専攻を修了した教員 も講義を担当する。放射線基礎, 放射線計測, 核融合に 関連する講義を予定している。

また，本講義を全て聴講した学生を対象とし，原子力 機構において 3 日間の実習を実施した。講義や実習，見 学を組み合わせ，学生の理解をさらに深めさせるように 試みた。

（3） テキストの作成

平成 23 年度〜平成 25 年度に実施した文科省事業によ り，高専生および技科大生向けのテキスト「基礎原子力 工学」を作成し，主に高専内で使用している。その基礎 的な部分を対象に英文化を進め, 高専の専門課程で実施 される英語教育において使用することを目指している。 内容はエネルギー需給と原子力の状況, 放射線の基礎, 放射線計測等からなる。また, 高専で使用可能な実習テ キストとして，GM 計数管を用いるもの等を開発してい る。完成後は各高専に配布し, 実験・実習で活用する予 定である。

（4）各高専における卒業研究・特別研究

高専では, 本科 5 年次に卒業研究を, また専攻科に進

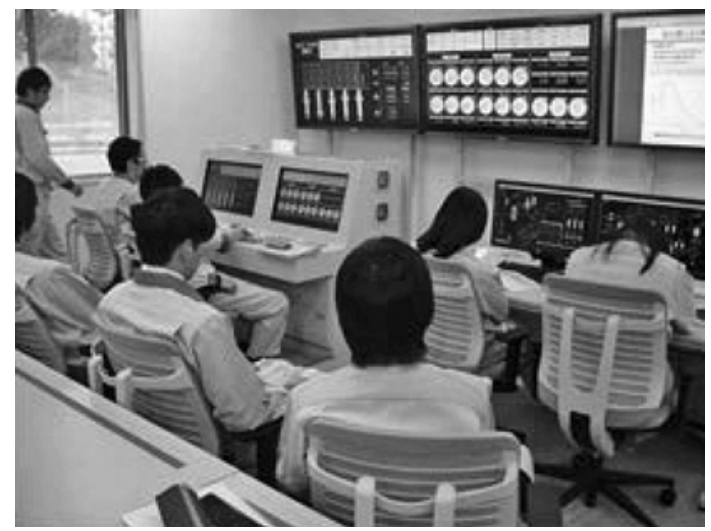

第 2 図 日本原子力研究開発機構における実習の様子 
学した学生は専攻科での 2 年間を通じて特別研究を実施 する。その中で各担当教員の指導のもと, 原子力・放射 線に関するテーマを取り扱った。また，その一環とし て, 25 の高専に执いて $\mathrm{NaI}(\mathrm{Tl})$ シンチレーションサーベ イメー夕による測定を継続して実施した。さらに，ポ ケット線量計を各高専で順次使用し, 低学年学生に数日 ～1 週間の継続測定を行わせることで, バックグランド 放射線についての理解を促す取り組みも行った。平成 26 年度にポケット線量計による測定を経験した学生は, 25 高専 777 名であった。

\section{3. 高専における廃炉教育}

国家課題である福島第一原子力発電所廃止措置を進め ていく上で中長期的な観点からの中堅技術者育成は堻緊 の課題であるとともに，実践的な中堅技術者を育成して いる国立高専の課題である。特に, 国立高等教育機関の 中で福島第一原子力発電所に最も近い場所に立地してい る福島高専には，全国の高専を廃炉教育の分野で牽引す る立場が求められている。そこで中長期的な視点での人 材育成及び大学・研究機関との連携を進めるために, 「廃 止措置人材育成高専等連携協議会 (略称: 廃プロ高専 協)」を平成 27 年 3 月 17 日に設立した。事務局を福島高 専内に置き, 初代会長に中村隆行福島高専校長, 副会長 に丁子哲治鹿児島高専校長が就任した。平成 27 年 4 月 現在で 28 高専, 5 大学, 3 自治体関係, 4 民間企業が加入 しており，今後，会員増強に努める予定である。

廃プロ高専協の設立に伴い, 福島高専で会員校対象の 廃炉学修プログラムの立ち上げを検討している。先行し て廃炉に関する授業を平成 27 年度から 2 科目新規に立 ち上げ, GI-netを活用した遠隔授業を開始する。授業は 3 年生対象の「廃炬と社会」, 4 年生対象の「廃炉工学」で あり，いずれも 1 単位，集中講義形式で実施する。

「廃炉と社会」では，福島第一原子力発電所の廃炬に向 けて社会的㑯面も含めて必要とされる基礎知識を修得さ せる。また, 廃炬に先行して関連する放射線や除染, 中 間貯蔵施設についても考える内容とし, さらに地球大気 形成の歴史やウラン資源形成, 生物学や物理学, ロボッ 卜，廃棄物処理などに関する基礎的な講義のほか，廃炉 に向けた地域住民とのコミュニケーション手法を理解す るためのグループワークを実施予定である。

「廃炉工学」では, 軽水炉の構造や中性子の振舞, 原子 力発電所の廃炬とスリーマイル島 (TMI) やチェルノブ イリの原子力事故について学習する。また, 福島第一原 子力発電所廃炉に向けた中長期ロードマップの理解と, 放射性廃棄物の処理処分についても考えさせる。どちら の講義も, 講義時間帯が合わない場合や, 既存の講義の 一部としても活用できるようにするために, 講義の様子 を録画して抄き，必要に応じて使用できるように共有化 を図る。また，高専機構で実施している「国際原子力人
材育成イニシアティブ事業」で整備しているコンテンッ も活用し，内容の充実化を図る予定である。講師は，廃 プロ高専協に参加している高専教員や大学教員, 企業や 研究機関の技術者・研究者等に依頼し, 全国から幅広い 分野の講義を実施する。平成 28 年度には更に講義 1 科 目と実験・実習 1 科目を立ち上げ，インターンシップや 研究連携の枠組みを整理し, 原子力機構楢葉遠隔技術開 発センターの積極的利用も含め, 高専全体での廃炉教育 を充実させる予定である。

高専の本科は 16 歳から 20 歳までの幅広い年齢の学生 が在籍していることから, 早期の一貫した教育が可能で ある。その利点を生かし, 福島高専では平成 18 年度か ら全学科の 2 年生を対象に全教員の指導のもと, 自由な 発想と創造性を育むための新たな試みとして「ミニ研究」 の科目を導入し実施している。これは半期 1 単位で, 一 般, 専門を問わず全教員に数名の学生が割り当てられ, 学生が教員の専門分野に関するテーマで研究に取り組む 授業である。平成 27 年度は「福島第一原子力発電所の廃 炉について考元る」というテーマで, 電気工学科 3 名, 建 設環境工学科 1 名の 4 名が研究を開始した。今後, 福島 第一廃止措置に関する正確な情報を収集し，廃止措置が 進んでいる日本原子力発電東海発電所の見学などを通 じ, 学生自らの目で見て, 直接耳で聞いて廃炉に必要な 技術を調べると同時に，廃炉に関する学生の関心を更に 高めたい。

\section{II. 長岡技科大における高専の原子力人材 育成との連携}

\section{1. 長岡技科大と高専の関係}

長岡技科大は創造的指導的技術者を育成するための新 構想大学として, 昭和 51 年に設置された大学である。 高専で 5 年間あるいは専攻科を含めて 7 年間の技術者教 育を受けた言わば技術者のサラブレットと言える学生た ちを, 3 年生編入あるいは大学院で受け入れてょり一層 の創造性を育むと共に，技術者のリーダーとして育て上 げるというのが長岡技科大の役割である。学生定員の $80 \%$ が高専生の 3 年生編入であり, まさに高専生の大学 である。

長岡技科大は高専から学生を引き受けるだけでなく, 高専と協力しながら教育活動も行っている。したがっ て, 原子力分野でも高専と連携しながら人材育成を行っ ているのである。

長岡技科大では, 高専生を対象とした講義と実習を準 備している。講義では, 原子力の基礎, 原子力安全, 放 射線の基礎，放射線の応用などを行っている。また，実 習では静電加速器を用いた実習, 天然放射性物質を捕集 し測定する実習，天然放射性物質を用いた分離実習，天 然ウランを含んだ物質を用いた天然ウランの放射能と性 状を学ぶ実習などを行っている。特に実習では自然界に 


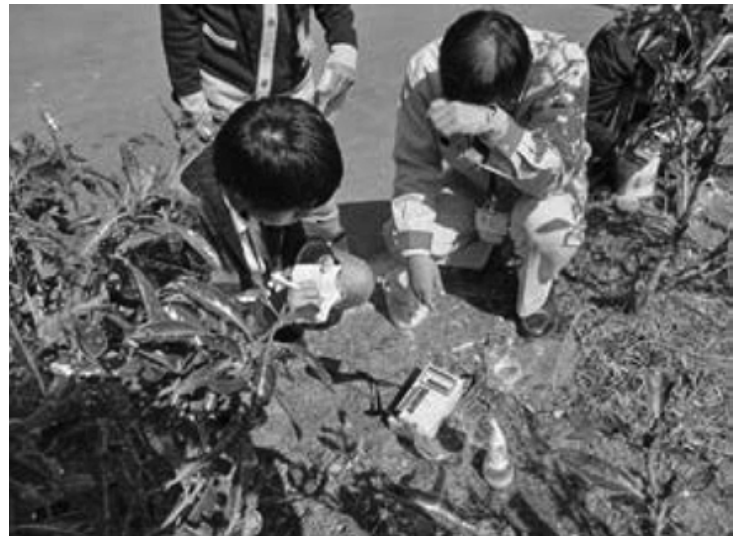

第 3 図 污染土壤の線量測定風景

ある放射性物質を用いることによって，実習生に対して 放射線によるリスクを最小限に抑えて，放射性物質の取 扱や測定に関する基礎を学ぶと共に放射線や放射性物質 に対してむやみに恐れることなく，対応できるようにす ることを目指している。

\section{2. フィールドでの実習や原子力施設等見学}

長岡技科大では, 福島高専や茨城高専と連携しフィー ルドでの実習を行っており，福島第一原子力発電所事故 の影響を理解するため, 線量測定の実習, 除染現場の見 学や除染の体験, 除染で発生した污染土の仮置き場の見 学を行っている(第3 図)。施設見学では, 長岡技科大が 柏崎刈羽原子力発電所から $15 \mathrm{~km}$ 圈内であるという状況 も利用し, 発電所見学や関連施設の見学を行っている。

3. 放射線利用施設を用いた共同利用・共同研究 長岡技科大は，放射線利用施設であるラジオアイソ トープセンター (RI センター) や極限エネルギー密度工 学研究センター，また，新たに設置された静電加速器な どを，共同利用あるいは共同研究のため全ての高専に開 放している。 RI センターでは $\alpha$ 核種であるアクチノイ ドも利用可能であり，原子力人材育成に必要な放射性核 種は，ほぼ全て利用できる。また，一般的な放射線測定 器に加え, 誘導結合型プラズマ質量分析装置(ICP-MS) が管理区域内に設置してあることも RI センターの特徵 である。ICP-MS では長半減期核種の測定だけでなく, 安定核種の測定も可能であるため，実施できる化学実験 の幅が広い。

放射線発生装置としては，コッククロフト型の静電加
速器に加え, エネルギーの異なる大電流 $(\mathrm{kA}$ を超える電 流)を発生させるパルス発生装置 (ETIGO-II， III， IV)な ど世界的に見てもユニークなものがそろっている。現状 では，これらの施設・設備が共同利用あるいは共同研究 用として高専に十分に利用されているとは言えない。ま ずは試験的な試みでよいので, ぜひ長岡技科大 RI セン ターに問い合わせをいただければと思っている。

長岡技科大においては，今後も放射線利用施設掞よび 関連施設を活用した高専原子力人材育成を行いたいと考 えており, 高専でも高専生のインターンシップ, 教育研 究で積極的に長岡技科大を利用してもらいたい。

\section{III.まとめ}

国立高専機構および長岡技科大では，連携して原子力 人材育成に取り組み，成果を上げてきた。我が国の電力 安定供給に資するため, 今後も原子力分野に必要な実践 的技術者の育成に貢献するよう努めてまいる所存であ る。学会関係の皆様のご支援をお願いしたい。

\section{著者紹介}

紀聖治（きの・せいじ）

国立高等専門学校機構 理事

(専門分野/関心分野)工学教育，組織マネジメント

高田英治（たかだ・えいじ）

富山高専 電気制御システム工学科 教授

(専門分野/関心分野)放射線計測，原子力教育

鈴木茂和（すずき・しげかず）

福島高専 機械工学科 准教授

(専門分野/関心分野) 核融合炉材料強度評価，廃止措置，口 ボット

太田泰雄（打おた・やすお）

長岡技術科学大学 特任教授・特命教授

(専門分野/関心分野) 原子力教育, リサーチ・アドミニスト レーター (URA)

鈴木達也（すずき・たつや）

長岡技術科学大学 教授

ラジオアイソトープセンター長

(専門分野/関心分野) 核燃料サイクルにおける分離，使用済 み燃料の核種分離による廃棄物の減容化，同位体分離技術 による原子力や他分野への応用 